\title{
Teachers' Concern and Professional Development Needs in Adopting Inclusive Education in Saudi Arabia, Based on Their Gender for Vision 2030
}

\author{
Abdullah Ali Asiri ${ }^{1}$ \\ ${ }^{1}$ Ministry of Education, Special Education Department, Riyadh, Saudi Arabia \\ Correspondence: Abdullah Ali Asiri, Ministry of Education, Special Education Department, 13223 Al Khaleej, \\ Riyadh, Saudi Arabia. E-mail: almohom@gmail.com
}

Received: September 1, 2020 Accepted: October 6, 2020 Online Published: October 23, 2020

doi:10.5539/jel.v9n6p9 URL: https://doi.org/10.5539/jel.v9n6p9

\begin{abstract}
This study looks into the concerns and the required professional development for adopting an inclusive education system, as expressed by elementary school teachers, based on their gender in Saudi Arabia. Participants in this research were special and general education teachers randomly selected from elementary schools in Riyadh, Saudi Arabia, which have special education programs. The theoretical framework of the study was the Concern Based Adoption Model (CBAM). Non-experimental cross-sectional survey was used to collect data. Data were obtained from 332 teachers, i.e., the response rate was $83 \%$. The Stages of Concerns Questionnaire (SoCQ) provided by CBAM indicated that respondent stages of concern 0-2 (Unconcerned, Informational, and Personal) ranked the highest, while stages 4-6 (Consequence, Collaboration, and Refocusing) ranked the lowest. This profile was identified as a "non-user profile", meaning respondents wanted more information about inclusive education. Teachers, in general, showed interest for professional development on inclusive education, including immediate training and seminars/workshops. The only significant difference in interest for professional development was by gender. The t-test indicated that female teachers have more interest for professional development compared to male teachers.
\end{abstract}

Keywords: inclusive education, gender, Saudi Arabia, disabilities, vision 2030

\section{Introduction}

According to Uditsky (1993), in inclusive education, the student with a significant disability, regardless of the degree or nature of that disability, is a welcomed and valued member in the neighborhood school. Regular classroom teacher teaches the student, and the teacher receives support as and when required. She/he follows the regular curriculum (with modification and adaptation), makes friends, and contributes to the learning of the entire class [and] participates in all aspects of school life, according to his/her interests and moves year-to-year with his/her peers from kindergarten through high school (p. 79).

Most studies on inclusive education have investigated the differences in teachers' attitude based on gender. Two studies found that male teachers have a more positive attitude toward inclusive education compared to female teachers (Chopra, 2008; Alquraini, 2011). Few other studies state that female teachers have a more positive attitude toward teaching students with disabilities in their regular classrooms (Vaz et al., 2015; Tabakhmelashvili, 2008; Al-Zyoudi, 2006). In addition, some studies found that there is no effect of gender on teachers' attitude in how they perceive inclusive education (Alghazo, Dodeen, \& Algaryouti, 2003; Woodcock, 2013). Therefore, this study reports an investigation of the concerns and the required professional development involved in adopting inclusive education, as expressed by elementary school teachers based on their gender in Saudi Arabia.

\subsection{Overview of the Kingdom of Saudi Arabia}

King Abdul-Aziz bin Abdul-Rahman Al-Saud unified a great part of the Arabian Peninsula in 1932, and the country was named the Kingdom of Saudi Arabia. It is an Islamic state with Arabic as its national language and the Holy Qur'an as its constitution (about Saudi Arabia, n.d.). KSA is located in the Middle East and is bordered on the north by Jordan, Iraq, and Kuwait, and on the east by Bahrain, United Arab Emirates, Qatar, and the Arabian Gulf Sea. The south is bordered by Oman and Yemen, and the west is bordered by the Red Sea. KSA dominates the Arabian Peninsula in terms of land area, having over two million square kilometers of land 
(Alquraini, 2011). Over 31 million people live in Saudi Arabia, according to the General Authority of Statistics (2016). The geography of Saudi Arabia varies from north to south and includes mountains, plains, and deserts. The temperature varies from over one hundred degrees Fahrenheit in the daytime to well below 30 degrees on a cold desert night. Riyadh is the capital city of Saudi Arabia. The economy in KSA is driven by oil. According to the National Geographic Society (2014), oil was discovered in Saudi Arabia in 1938. It is now ranked second in the world in oil production, according to the U.S. Energy Information Administration (2017). According to the Economic Freedom index (2016), oil's income accounts in KSA for about 90\% of export earnings and about 80\% of government revenues. Government envisions that by 2030 they will start to raise non-oil revenues, as they strive to reduce the dependence on oil (Transformation Program, 2016). Saudi Arabia is now moving toward a more inclusive vision known as Vision 2030 that aims to create a vibrant society, a thriving economy, and an ambitious nation (Vision 2030, 2016). Therefore, the Government of Saudi Arabia has created a National Transformation Program, which is currently running in all those KSA institutions that aim to achieve the Vision 2030 goals (Transformation Program, 2016).

The government system of KSA is a theocratic monarchy. It is ruled over by a royal family, and the current King is Salman ibn Abdul-Aziz. The King rules the country according to the Sharia law, which is based on the Qur'an and Sunnah. According to Islam web (2018), Sunnah is "Anything narrated from or about the Prophet Mohammed either before or after he became a prophet, of his statements, actions, confirmations, biography, and physical characteristics and attributes" (p. 2). By far, the dominant religion in KSA is Islam. Under Sharia law, certain rights are applied equally to all people, such as living with dignity, healthcare, and education (Alquraini, 2011; The World Factbook, 2016).

\subsection{Development of the Education System in KSA}

Before the establishment of the KSA in 1932, education was the privilege of only the male members from elite and wealthy families. The form of education that was practiced at that time was teaching students how to read and write Arabic as well as how to recite the holy Qur'an. Mosques and Quranic schools were the educational institutes at that time (Alrashidi \& Phan, 2015; Alquraini, 2011).

King Abdul-Aziz founded the Directorate of Education before the unification of the entire country and the proclamation of the Kingdom of Saudi Arabia in 1932 (Alrashidi \& Phan, 2015, p. 34). The responsibility of the Directorate of Education was to establish public schools across the country. As stated earlier, tradition and culture allowed only male members of the society to have education at that time (Alsharif, 2011; Wiseman, 2010). In 1960, formal education was allowed to females, but separate from males. This gender separation continues even today (Al-Zarah, 2008). Today there are more than 30,000 public schools for both genders in KSA (Alrashidi \& Phan, 2015). In addition, there are 34 universities and about 72 private colleges. Education opportunities have expanded at all levels and for both genders (Oxford Business Group, 2015).

The Qur'an and Sunnah rules influence the education system in KSA, which means that at all levels of education there are different religious subjects that students have to take. However, the education institutions also impart knowledge in most subjects, such as mathematics, science, history, physics, geography, art, and physical education (Alquraini, 2011).

Additionally, traditions and culture influence education. At all levels, most female and male students receive their education separately from teachers of respective genders.

\subsection{Development of Special Education in the Kingdom of Saudi Arabia}

The Special Education Department in the Ministry of Education was established in 1962, to provide special education services to visually impaired and deaf male students in private institutes (Aldabas, 2015). Then, in 1971, the Ministry of Education established the first special education school by the name of Intellectual Education Institute. The main purpose of this school is to provide education services and lifelong skills to students with intellectual disabilities (Aldabas, 2015). Between 1990 and 2000, the Ministry of Education started to open integration programs for special education classes in regular elementary schools. The idea was to provide educational services to students with mild to moderate intellectual disabilities, mild to moderate autism disorders, and hearing impairment (Aldabas, 2015).

In Saudi Arabia, students with special needs were typically placed in special education institutes or self-contained classrooms in regular elementary schools. In self-contained classrooms, students with disabilities usually do not learn or interact with their non-disabled peers (Al-Mousa, 2010). They do not engage with other students in academic or extracurricular activities. There are studies that show that integration into regular school is the appropriate strategy to enhance education and social interaction for students with disabilities (Alkashrami, 
2001). In recent times, the Ministry of Education in Saudi Arabia has shown interest in inclusive educational teaching practices. As per this, students with special educational needs are placed in regular public education classrooms and are taught alongside their non-disabled peers (Al-Mousa, 2010). However, this is yet to be applied effectively across all public schools in Saudi Arabia.

\subsubsection{Legislation for Special Education}

In Saudi Arabia, students with disabilities have the legal right to free educational services. The Ministry of Labor and Social Development (2000) provided the Disability Welfare Law in Saudi Arabia. Article 2 (Educational Aspects) states, "Provide educational services in all levels of education from preschool, general education, technical education, and higher education in the way that meets the abilities and needs of the disabled. Facilitate the enrollment and continued evaluation of the curriculum and the provided educational services." In the United States of America, the 2004 Individuals with Disabilities Education Improvement Act (IDEIA) further states that the services must be provided in the least restrictive environment (IDEIA, 2004). Clear and comprehensive education legislation can help to protect the rights of individuals with disabilities to appropriate education without any discrimination (Andrews \& Lupart, 2000; Bauer \& Brown, 2001; Loreman, 2001; Loreman et al., 2005; Loreman, 2007).

\subsection{Vision 2030}

The government of Saudi Arabia created a transformation program toward a vision called Vision 2030. The purpose of this transformation program is to improve the entire system in the country by 2030, which includes economy, healthcare, safety, and education. According to the National Transformation Program for Vision 2030 (2016), this vision "was adopted as a methodology and roadmap for economic and developmental action in the KSA" (p. 7). In Vision 2030, the government focuses on eight objectives related to education reform:

1) Provide education services for all student levels

2) Improve recruitment, training, and development of teachers

3) Improve the learning environment to stimulate creativity and innovation

4) Improve curricula and teaching methods

5) Improve students' values and core skills

6) Enhance the educational system's capability to address national development requirements and to meet labor market demands

\subsection{Research Purpose}

This study investigates the concerns and required professional development for adopting an inclusive education system, as expressed by elementary school teachers in Saudi Arabia. The goal is to understand the different requirement for female and male teachers in adopting an inclusive education. In addition, this study was conducted to provide baseline information to the Department of Planning and Development in the Ministry of Education for adopting an inclusive education system. The main purpose of this new education system is to provide increasing number of students with disabilities appropriate special education services.

\subsection{Research Questions}

There are four research questions:

Research Question 1: What is the relationship between teachers' gender and concerns about adopting inclusive education?

Research Question 2: Are the teachers' recognition of administrative support (administrators in school and administrators in the district department of education) for inclusive education related to teachers' gender?

Research Question 3: Are teachers' attitude toward adopting inclusive education related to teachers' gender?

Research Question 4: Are teachers' requirements for professional development for inclusive educated related to teachers' gender?

\section{Theoretical Framework: The Concerns-Based Adoption Model}

The Concerns-Based Adoption Model (CBAM) is a conceptual framework that describes, explains, and predicts probable behaviors throughout the change process. It can help educational leaders, coaches, and staff developers facilitate the process (George, Hall, \& Stiegelbaurer, 2013, p. 5). Hall, Wallace, and Dossett founded it in 1973, based on the work of Fuller (1969). The CBAM's focus is on what happens to teachers when presented with change (Hall, Wallace, \& Dossett, 1973). In addition, it provides tools and strategies for comprehensive 
management of educational innovations to facilitate the implementation process.

\subsection{Stages of Concern}

Hall, George and Rutherford (1998) describe the concept of "concerns" as "the composite representation of feelings, preoccupation, thought and consideration given to a particular issue or task." Depending on the personal make-up, knowledge and experience, each person perceives and mentally contends with a given issue differently; thus, there are different kinds of concerns (p. 5). The primary tool in the CBAM is the Stages of Concern (George, Hall, \& Stiegelbaurer, 2013). Frances Fuller is a counseling psychologist at the University of Texas. It was her idea to term teachers' feelings and perceptions about innovation and the change process as "concerns" (Hall \& Hord, 2006). After further research, Fuller proposed that there are four levels of this concern.

- Unrelated Concerns: This type of concern is most frequently found among student teachers or prospective teachers who do not have direct contact with students.

- Self-Concerns: This type of concern is typically found among new teachers. Their concern is about the success for themselves rather than actual teaching or the students' needs.

- Task Concerns: This comes after teaching. Teachers' concerns begin to be centered more on the teaching process, to include materials, preparation, coordination, and scheduling.

- Impact Concerns: At this level, teachers' concerns are about improving themselves, so that they can be more effective as teachers and improving students' outcomes (Hall \& Hord, 2006).

\subsection{The Seven Levels of Concerns about Innovation}

- Level 0-Unconcerned: The individual indicates little concern about or involvement with the innovation.

- Level 1-Informational: The focus is on the general awareness of the innovation and interest in learning about it. The person does not seem to be worried about one's self in relation to the innovation. She/he is interested in substantive aspects of the innovation in a selfless manner, such as general characteristics, effects, and requirements for use.

- Level 2-Personal: The individual is uncertain about the demands of the innovation, his/her inadequacy to meet those demands, and his/her role in respect to the innovation. This includes analysis of one's self in relation to the reward structure of the organization, decision-making, and consideration of potential conflicts with existing structures or personal commitment. There is also concern about the financial or status implications of the program for self and colleagues.

- Level 3-Management: The focus is on the process and tasks of using innovation and the best use of information and resources. Issues related to efficiency, organizing, managing, scheduling, and time demands are of utmost importance.

- Level 4-Consequence: The focus is on the impact of the innovation on "clients" in the immediate sphere of influence.

- Level 5-Collaboration: The focus is on coordination and cooperation with others regarding the use of the innovation.

- Level 6-Refocusing: The focus is on the exploration of more universal benefits from the innovation, including the possibility of major changes or replacement with a more powerful alternative. The individual has definite ideas about alternatives to the proposed or existing form of the innovation (George et al., 2013, p. 8).

\section{Research Methodology}

A non-experimental, cross-sectional survey was the research design used to address the research questions in this study. Close-ended questions, distributed through electronic medium, were used to collect quantitative data for the study. A series of one-way Multivariate Analysis of Variance (MANOVA) was used to find values of significance. MANOVA was used to test whether there are statistically significant differences among groups on multiple dependent variables. In addition, MANOVA can protect against Type I errors (rejection of a true null hypothesis) (French, Poulsen, \& Yu, 2006). SPSS, the statistical platform was used to provide different statistical tests based on MANOVA, such as Pillai's Trace statistic, which was used to determine statistical significance at the $\mathrm{p}<0.05$ level. When the MANOVA reveals statistically significant differences, then an Analysis of Variance (ANOVA) test is conducted to identify the values of significance. The size of the study sample was 400 teachers. Data were obtained from 332 teachers, a response rate of $83 \%$. 


\subsection{Study Variables}

The independent variable in this study is the gender. There are four dependent variables: Stages of Concerns, Administrative Support, Prior Instructional Training, and Attitude toward Inclusive Education.

Table 1. Summary of the independent and the dependent variables in the study

\begin{tabular}{ll}
\hline Variables & Level of Measurement \\
\hline Independent Variable & \\
Gender & Nominal \\
Dependent Variables & \\
Stages of Concerns & Interval \\
Administrative Support & Interval \\
Prior Instructional Training & Interval \\
Attitude toward Inclusive Education & Interval \\
\hline
\end{tabular}

\section{Data Analysis}

\subsection{Descriptive Statistic}

Participants in this research were male and female special and general education teachers randomly selected from elementary schools in Riyadh, Saudi Arabia, which have special education programs. The data were analyzed using descriptive and inferential analysis. Descriptive data analysis revealed that $45 \%$ of the participants were female, while $38 \%$ of the participants were male.

Table 2. Summary of participant

\begin{tabular}{lll}
\hline Variable & Total Number $(\mathbf{N}=\mathbf{3 3 2})$ & Total Percentage $\mathbf{8 3 \%})$ \\
\hline Gender & & \\
Male & 151 & $38 \%$ \\
Female & 181 & $45 \%$ \\
\hline
\end{tabular}

\subsection{Research Question 1 - Results}

What is the relationship between teachers' gender and concerns about adopting inclusive education?

Using the respondent stages of concern, Stages 0 to 2 were the highest, and Stages 4 to 6 were the lowest. The highest stage of concern for respondents was Stage 0 (Unconcerned), indicating that these respondents had little concern about or involvement in inclusive education. The second highest stage score was Stage 1 (Informational), indicating that the respondents wanted more information about inclusive education.

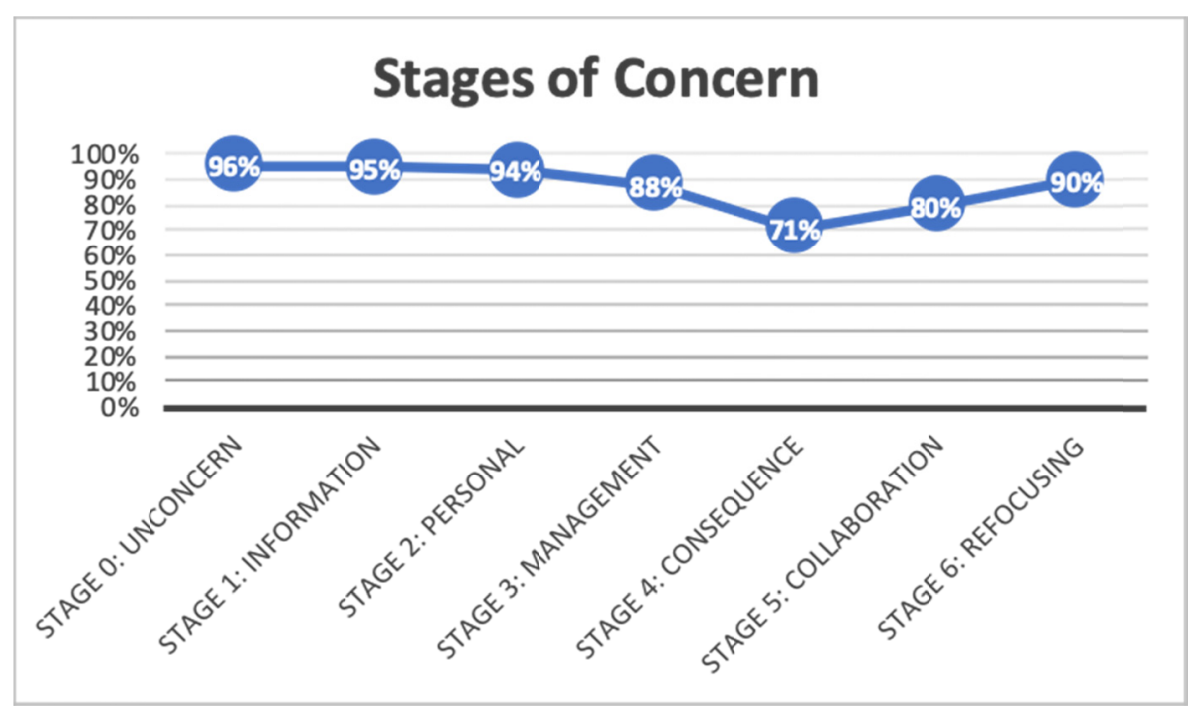

Figure 1. Stages of Concern profile for respondents 
A one-way MANOVA test indicated that there is no statistically significant difference between respondents' gender and concerns about adopting inclusive education.

Table 3. Results summary of Pillai's Trace test of MANOVA on stages of concerns

\begin{tabular}{lllllll}
\hline Independent Variable & Value & $\boldsymbol{F}$ & $\boldsymbol{d} \boldsymbol{f}$ & Error $\boldsymbol{d} \boldsymbol{f}$ & Sig & Eta \\
\hline Gender & .010 & .488 & 7 & 324 & .843 & \\
\hline
\end{tabular}

Note. None of the findings reached a statistically significant level of $\mathrm{p}<0.05$.

\subsection{Research Question 2 - Results}

Are the teachers' recognition of administrative support (administrators in school and administrators in the district department of education) for inclusive education related to teachers' gender? Based on the descriptive statistics, the responses almost converged between agreement and disagreement, with slightly more respondents agreeing that administrator support of inclusive education was present.

The MANOVA test results indicated that there is no statistically significant difference between respondent gender and recognition of administrator support of inclusive education.

Table 4. Pillai's Trace test results of MANOVA for teacher recognition of administrator support for inclusive education

\begin{tabular}{lllllll}
\hline Independent Variable & Value & $\boldsymbol{F}$ & $\boldsymbol{d f}$ & Error $\boldsymbol{d f}$ & Sig & Eta \\
\hline Gender & .003 & .534 & 2 & 329 & .587 & \\
\hline
\end{tabular}

Note. None of the findings reached a statistically significant level of $\mathrm{p}<0.05$.

\subsection{Research Question 3 - Results}

Are teachers' attitude toward adopting inclusive education related to teachers' gender? Descriptive statistics showed that respondents are positive about inclusive education. The MANOVA test indicated no statistically significant differences between respondents' personal characteristics and their attitude toward adopting inclusive education. Therefore, it was null hypotheses for question 3.

Table 5. ANOVA: Results for teacher attitudes toward inclusive education

\begin{tabular}{llllll}
\hline Independent Variable & Type III SS & $\boldsymbol{d} \boldsymbol{f}$ & Mean Square & F & Sig \\
\hline Gender & .391 & 1 & .391 & .405 & .525 \\
\hline
\end{tabular}

Note. None of the findings reached a statistically significant level of $\mathrm{p}<0.05$.

\subsection{Research Question 4 - Results}

Are teachers' requirements for professional development for inclusive educated related to teachers' gender? Descriptive statistics indicated that most respondents agreed on the need for professional development for inclusive education. The ANOVA test results indicated a statistically significant difference between respondents based on gender and the need for professional development for inclusive education.

Table 6. ANOVA results for teachers and their need for professional development in inclusive education

\begin{tabular}{lllllll}
\hline Independent Variables & Type III SS & $\boldsymbol{d f}$ & Mean Square & F & Sig & Eta \\
\hline Gender & 3.900 & 1 & 3.900 & 5.559 & .019 & .017 \\
\hline
\end{tabular}

Note. Findings that approach statistically significant level, depending on the $\mathrm{p}$ value: Significant at the $\mathrm{p}<0.05$ level.

The $t$-test showed that female respondents are more likely to see the need for such professional development compared to the male teachers. Therefore, null hypothesis $H O$ was rejected. 
Table 7. Mean of responses by gender on the need for professional development in inclusive education

\begin{tabular}{llllll}
\hline Dependent Variable & Gender & N & Mean & SD & Sig \\
\hline Professional Development Need & Male & 151 & 3.7 & .91 & .019 \\
& Female & 181 & 4 & .77 & \\
\hline
\end{tabular}

Note. $\mathrm{N}=$ Sample number, $\mathrm{M}=$ Mean, $\mathrm{SD}=$ Standard deviation, $\mathrm{Sig}=$ Significant at the $\mathrm{p}<0.05$ level.

\section{Results}

\subsection{Stages of Concern}

The highest respondent stages of concern were Stages 0 to 2, and Stages 4 to 6 were the lowest. The highest stage among respondents was Stage 0 (Unconcerned) (see Figure1), indicating that these respondents had little concern about or involvement in inclusive education. The second highest stage score was Stage 1 (Informational), indicating that respondents wanted more information about inclusive education. This was a common concern among individuals who were yet to begin using inclusive education. Their profiles indicate a "non-user profile", which is frequently found in institutions where inclusive education is only beginning to be implemented.

\subsection{Administrative Support for Inclusive Education}

For teacher's recognition of administrative support (administrators in schools and district administrators) for inclusive education, responses converged between agreement and disagreement, with slightly more respondents agreeing that administrators supported inclusive education.

\subsection{Attitudes toward Inclusive Education}

Teachers in this study have a positive attitude toward inclusive education. Most responses indicated that teachers are interested and willing to change their teaching methods to adopt inclusive education. In addition, the responses indicated that teachers are interested in learning through workshops about adopting inclusive education (Table 5).

\subsection{Required Professional Development for Inclusive Education}

The professional development that is required for inclusive education include a curriculum training that enhances inclusive education, special education teachers to support teaching in an inclusive education classroom, and seminars/workshops to enhance teacher knowledge about this program. Teachers' responses were significantly positive about professional development for inclusive education.

\section{Discussion and Conclusions}

Teachers' responses indicate that they are in need of professional development. More than four-fifths of the responses agreed that teachers needed immediate training in inclusive education curriculum, professional assistance to support their teaching, and seminars/workshops on inclusive education.

Gender showed the only significant difference $(p=0.019)$ with the $t$-test indicating that female teachers wanted professional development $(M=4)$ more compared to male teachers $(M=3.7)$.

Women in Saudi Arabia are struggling to pursue careers outside their homes because of widespread gender stereotypes, which enforces that women are valued only in their roles as homemakers, mothers, and wives (Al-Asfour \& Khan, 2014). In addition, these cultural and social values work as a barrier preventing women from advancing in their careers (Tlaiss, 2015). However, despite these barriers, increasingly women in Saudi Arabia are enrolling for formal education and striving for a professional career (Al-Ahmadi, 2011).

According to the National Transformation Program (2016) theme number six, Labor Market Accessibility \& Attractiveness, the first objective is to increase women's participation in the labor market: "Increase the contribution of women to economic and social development, by raising their participation in the labor market in all sectors. Also, by removing the barriers that stand in the way of their joining the labor market" (The National Transformation Program, 2016, p. 80). To achieve this objective, the program recommends four strategies:

- Increase women's share in the labor market through training and awareness.

- Increase women's share in managerial positions through training and leadership orientation for women, empowering women in the civil service and strengthening their leadership roles.

- Promote the culture of work and develop skills (personal and technical) for women.

- Develop support for women who are employed (e.g., transportation, crèches and nurseries, and attractive work environment) (The National Transformation Program, 2016, p. 81). 
Due to the National Transformation Program that started in 2016, we can see that women in Saudi Arabia have gained some rights, such as driving cars and attending soccer matches. Women who are more qualified are now in managerial positions. Both Vision 2030 and the National Transformation Program make it easy to see why women feel the need for professional development more compared to men.

While examining the Saudi Disability Welfare Law (2000), I realized that it lacked proper support for inclusive education. The Saudi Disability Welfare Law article 2 (Educational Aspects) states, "Provide educational services in all levels of education from preschool, general education, technical education, and higher education in the way that meets the abilities and needs of the disabled. Facilitate the enrollment and continued evaluation of the curriculum and the provided educational services" (The Ministry of Labor and Social Development, 2000, p. 2). In Saudi Arabia, one cannot accurately track the extent of the needs and challenges of the disabled, as the country lacks a clear-cut definition of disability. The country also lacks a standardized and unified database of people with disabilities. In addition, the country lacks the awareness regarding issues related to working with and educating people with disabilities, as well as the obstacles that they face. Furthermore, most work environments do not have accommodations for people with disabilities (Transformation Program, 2016).

Saudi Arabia is now moving toward a more inclusive vision known as the Vision 2030, which aims to create a vibrant society, a thriving economy, and an ambitious nation (Vision 2030, 2016). Therefore, the Government of Saudi Arabia created a National Transformation Program (Vision 2030, 2016). According to this program under theme number six (Labor Market Accessibility \& Attractiveness), the second strategic objective is to integrate people with disabilities into the labor force. This objective aims to "remove obstacles that hinder people with disabilities from integrating into the labor market by providing opportunities, establishing infrastructure and developing their professional and social skills" (Transformation Program, 2016, p. 80). One strategy that the Saudi government has included to achieve this objective is improving and supporting legislation, policies, and classifications by establishing the Authority of Caring for Disabled People to provide necessary services to the disabled (Transformation Program, 2016).

Thus, the support of administrators in schools or districts will be sufficient, if legislation supports inclusive education. School leaders will need to do more to encourage inclusive education, understand the workload, and organize collaboration between special and general educators. In addition, school and district leaders can help develop support systems by connecting school communities with other organizations that advocate the rights of the disabled. Vision 2030 promises improvement for the disabled, especially in legislation and policies for educating students with disabilities.

\subsection{Recommendations for Adopting Inclusive Education in Saudi Arabia}

The following are the specific recommendations based on the findings of the study. These recommendations may help the Saudi Ministry of Education to adopt inclusive education more efficiently and productively.

- Provide training programs on inclusive education based on stages of concern among teachers

Based on the collected data, the 0-2 stages of concern among respondents were the highest. This means that teachers understood very little about inclusive education. This result requires very careful attention. Intervention must include professional training and consultation depending on the current stage of concern. Professional development for a teacher with a high personal concern should be quite different from the one with high impact concern. Suggested strategies include:

- Teachers who are at Stage 0 (Unconcerned) should be involved in discussions, scenarios, and decisions about inclusive education. Also sharing enough professional information without overwhelming them is important in attracting their attention. Facilitating communication about inclusive education between general and special education teachers is one important way to let them share their concerns.

- Those at Stage 1 (Informational) should be provided with clear-cut information about inclusive education. This information should specifically include definitions of different types of disabilities; ways to adapt curriculum and environments for different types of special needs; assistive technology tools and how to use them in classes; and ways for special and general education teachers to collaborate. In addition, delivering this information to teachers should include e-mail, brochures, short media presentations, and workshops/seminars.

- Teachers at Stage 2 (Personal) may be concerned about the implications of inclusive education for themselves, especially if this is high. Acknowledging these personal concerns would be beneficial. Personal conversations with teachers may help them understand their own concerns and encourage them to find ways to reinforce personal adequacy.

- Target the most interested group for early adoption 
Stages of concern 0 to 2 were high and Stage 6 tail up, which means "non-user profile with resistance to change" see Figure 1. Addressing teacher resistance requires departments of education to adopt a plan that may include the following:

- Diagnose the resistance: Resistance may come from overwork, lack of information, fear of change, inadequate support, or lack of proper class or school environment.

- Target the most interested group first: School leaders should facilitate adopting inclusive education by addressing the concerns of special education teachers before beginning to place special need students in regular classrooms along with general education teachers.

- Early adopters can serve as guides: Once early adopters have attended workshops and constructed inclusive classes, they can then serve as guides to other teachers. It might be easier for concerned teachers to speak to their trained colleagues rather than the school administrators. It would be easier for teachers who serve as guide to approach teachers who may have resisted inclusive education.

- Provide any necessary support through school and district administrators

In this study, $62 \%$ of the teachers have no opinion or thought that administrator support for inclusive education is insufficient. Therefore, the Ministry of Education must start using reform legislations and policies related to the education of students with special needs. With clear-cut inclusive education policies, supportive administrators can offer support for inclusive education. Other administrators will then be encouraged to support and facilitate teacher's efforts in inclusive classes.

In addition, administrators can establish a sub-department in special education departments to support teachers in inclusive education by providing information, assistive technology, or any other support that teachers need in inclusive classes.

- Provide equal and adequate training and incentives to teachers adopting inclusive education

In this study, $86 \%$ of the teachers need immediate training on inclusive education through workshop and seminars. Thus, structured training sessions need to be designed for teachers. As education in Saudi Arabia is segregated by gender, providing equal opportunities for both genders is important in the workshops and training. The study reveals that female teachers are more inclined to receive professional development on inclusive education. Hence, there should be more seminars and training for female teachers. In addition, female teachers should be encouraged to share their points of view about the professional development structure to ensure quality and equity in future training programs.

- Develop a strategic plan for adopting inclusive education

A strategic plan will ensure inclusive education is applied continuously and in all departments of education across Saudi Arabia. The following plan may help in reaching these strategic plan goals:

- Provide training courses in inclusive education for prospective teachers in all grades and subjects.

- Provide continuing education for teachers who are already in the field.

- Follow-up in the field using a strict plan to ensure the inclusive education programs are on track.

- Provide incentives and rewards for teachers, both materially and morally, for successfully implementing inclusive education practices. These can be positive reinforcement and a good way to encourage other teachers to adopt inclusive education.

- Publish successful inclusive education experiences and generalize the experience to all targeted schools in Saudi Arabia.

\section{Recommendations for Future Studies}

This study was limited to elementary schools in Riyadh, Saudi Arabia. Therefore, it cannot be used as a generalized study for other cities or other departments of education in Saudi Arabia.

This study investigates teachers' concerns, attitudes, and required professional development through quantitative research. A qualitative study may provide a deeper understanding of teachers' concerns about inclusive education.

To expand on the current study, conducting interviews with participants ranked at Stage 0 (Unconcerned) (96\%) would be useful. Participants at this stage were the largest group, had the highest resistance to inclusive education, and are the most challenging group to work with. Interviewing them will help to determine the reason for their resistance. It can help to understand how to encourage them to adopt inclusive education. 
This study was limited to teachers' concerns. Other studies should be designed to investigate the concerns of students (both with special needs and with typical students), parents/guardians, and administrators to provide a comprehensive understanding of any concerns about inclusive education.

A study of the legislation and policies of educational care for individuals with disabilities would provide insight into how inclusive education could be modified to make it supportive.

\section{Delimitation of the Study}

This study was limited to a survey of teachers of elementary schools in Riyadh city, which have special education programs. All teachers in Saudi Arabia teach in public schools under the supervision of the Ministry of Education. This study took place during the spring of 2018 and examined the concerns and requirements for professional development for both special and general education teachers.

\section{Limitations of the Study}

The study, however, has few limitations. The survey is the research tool and the honesty of the participants cannot be controlled. In addition, some general education teachers may not be attentive to or interested in the topic of the study and as a result may not respond to the survey. The universality of the results might be questionable, as the study was limited to the city of Riyadh.

\section{References}

About Saudi Arabia. (n.d.). Retrieved from https://www.saudiembassy.net/history\#King\%20Abdulaziz

Al-Ahmadi, H. (2011). Challenges facing women leaders in Saudi Arabia. Human Resource Development International, 14, 149-166. https://doi.org/10.1080/13678868.2011.558311

Al-Asfour, A., \& Khan, S. A. (2014) Workforce localization in the Kingdom of Saudi Arabia: issues and challenges. Human Resource Development International, 17, 243-253. https://doi.org/10.1080/13678868.2013.836783

Al-Mousa, N. (2010). The experience of the kingdom of Saudi Arabia in mainstreaming students with special educational needs in public schools. Riyadh: The Arab Bureau of Education for the Gulf States. UNESDOC Digital Library. Retrieved from https://unesdoc.unesco.org/ark:/48223/pf0000191663

Al-Zarah, L. N. (2008). An investigative study of the female initial teacher preparation program in Saudi Arabia in an Islamic context: Perceptions of the key participants. Unpublished doctoral dissertation. University of Durham, Durham, UK. Retrieved from http://etheses.dur.ac.uk/1893/

Al-Zyoudi, M. (2006). Teachers' attitudes towards inclusive education in Jordanian schools [Electronic version]. International Journal of Special Education, 21, 55-61.

Aldabas, R. A. (2015). Special education in Saudi Arabia: History and hreas for reform. Creative Education, 6 , 1158-1167. https://doi.org/10.4236/ce.2015.611114

Alghazo, E. M., Dodeen, H., \& Algaryouti, I. A. (2003). Attitudes of Preservice Teachers Towards Persons with Disabilities: Predictions for the Success of Inclusion. The College Student Journal, 37, 515-522.

Alquraini, T. (2011). Special education in Saudi Arabia: Challenges, perspectives, future possibilities. International Journal of Special Education, 26, 139-147.

Alrashidi, O., \& Phan, H. (2015). Education context and english teaching and learning in the Kingdom of Saudi Arabia: An overview. English Language Teaching, 8, 33-44. https://doi.org/10.5539/elt.v8n5p33

Alsharif, K. M. (2011). Towards quality teacher education: Productive pedagogies as a framework for Saudi pre-service teachers' training in mathematics education. Unpublished doctoral dissertation. Curtin University, Perth, Australia. Retrieved from http://hdl.handle.net/20.500.11937/425

Andrews, J., \& Lupart, J. (2000). The inclusive classroom: Educating exceptional children (2nd ed.). Ontario: Nelson.

Bauer, A., \& Brown, G. M. (2001). Adolescents and inclusion: Transforming secondary schools. Baltimore: Paul H. Brookes.

Chopra, R. (2008). Factors influencing elementary school teachers' attitude towards inclusive education. Education Line, Kurukshetra University, Kurukshetra. Retrieved from http://www.leeds.ac.uk/educol/documents/174842.pdf

Dictionary.com. (2016). Sunna. Retrieved from http://www.dictionary.com/browse/sunnah 
Economic Freedom Index. (2016). Saudi Arabia. Retrieved from http://www.heritage.org/index/country/saudiarabia

French, A., Poulsen, J., \& Yu, A. (2006). Multivariate analysis of variance (MANOVA). Retrieved from http://userwww.sfsu.edu/\%7Eefc/classes/biol710/manova/manovanew.ht

General Authority of Statistics. (2016). The total population in 2016. Retrieved from http://www.stats.gov.sa/en/indicators/1

George, A., Hall, G., \& Stiegelbauer, S. (2013). Measuring implementation in schools: The stages of concern questionnaire. Austin, TX: Southwest Educational Development Laboratory. Retrieved from https://sedl.org/cbam/socq_manual_201410.pdf

Hall, G. E., George, A. A., \& Rutherford, W. L. (1998). Measuring stages of concern about the innovation: A manual for the use of the soc questionnaire. Austin: Texas University Research and Development Center for Teacher Education. Retrieved from https://files.eric.ed.gov/fulltext/ED147342.pdf

Hall, G. E., \& Hord, S. M. (2006). Implementing Change: Patterns, Principles, and Potholes. Boston: Pearson.

Hall, G., Wallace, R., \& Dossett, W. (1973). A developmental conception of the adoption process within educational institutions. Austin, TX: The University of Texas.

Individuals With Disabilities Education Act. (2004). Continuum of alternative placements [Section 300.115]. Retrieved from https://sites.ed.gov/idea/regs/b/b/300.115

Islamweb. (2018). The sunnah of the prophet: Definitions. Retrieved from http://www.islamweb.net/emainpage/printarticle.php?id=174849\&lang=E

Loreman, T. (2007). Seven Pillars of Support for Inclusive Education: Moving from. International Journal of Whole Schooling, 3, 22-38.

Loreman, T., Deppeler, J., \& Harvey, D. (2005). Inclusive education: a practical guide to supporting diversity in the classroom. Sydney: Allen \& Unwin. (Co-published in UK, USA, and Canada by Routledge Falmer. Co-published in India by Viva Books).

National Geographic Society. (2014). This day in geographic history: 1938: Oil discovered in Saudi Arabia. Retrieved from http://nationalgeographic.org/thisday/mar3/oil-discovered-saudi-arabia/

Oxford Business Group. (2015). Saudi Arabia expands educational offerings at all levels.

The Ministry of Labor and Social Development. (2000). Saudi arabia disability welfare law. Retrieved from https://mlsd.gov.sa/en/\%D8\%A7\%D9\%84\%D8\%B3\%D9\%8A\%D8\%A7\%D8\%B3\%D8\%A7\%D8\%AA-\% D9\%88-\%D8\%A7\%D9\%84\%D9\%84\%D9\%88\%D8\%A7\%D8\%A6\%D8\%AD/people-disabilities\%E2\%80 $\% 99$-care-system

The World Factbook. (2016). Background of Saudi Arabia. Retrieved from https://www.cia.gov/library/publications/the-world-factbook/geos/sa.html

Tlaiss, H. (2015). Neither-nor: career success of women in an Arab Middle Eastern context. Employee Relations, 37, 525-546. https://doi.org/10.1108/ER-03-2014-0028

U.S. Energy Information Administration. (2016). United States remains largest producer of petroleum and natural gas hydrocarbons. Retrieved from http://www.eia.gov/todayinenergy/detail.php?id=26352

Uditsky, B. (1993). From integration to inclusion: the Canadian experience. In R. Slee (Ed.), Is there a desk with my name on it? The politics of integration. USA: Falmer Press. Retrieved from https://www.family-advocacy.com/our-resources/from-integration-to-inclusion-the-canadian-experience/

Vaz, S., Wilson, F. N., Sim, M. et al. (2015). Factors Associated with Primary School Teachers' Attitudes Towards the Inclusion of Students with Disabilities. PLoS ONE, 10, e0137002. https://doi.org/10.1371/journal.pone.0137002

Vision 2030. (2016). National transformation program 2020. Retrieved from http://vision2030.gov.sa/en

Wiseman, A. W. (2016). The uses of evidence for educational policymaking: Global contexts and international trends. Review of Research in Education, 34, 1-24. https://doi.org/10.3102/0091732X09350472

Woodcock, S. (2013). Trainee teachers' attitudes towards students with specific learning disabilities. Australian Journal of Teacher Education, 38, 15-29. https://doi.org/10.14221/ajte.2013v38n8.6 


\section{Copyrights}

Copyright for this article is retained by the author, with first publication rights granted to the journal.

This is an open-access article distributed under the terms and conditions of the Creative Commons Attribution license (http://creativecommons.org/licenses/by/4.0/). 